УДК 004.75:339.138

- Маркетинг

JEL Classification: M15; M31; M37

\title{
ТЕХНОЛОГІЯ БЛОКЧЕЙН ДЛЯ ВИРІШЕННЯ ПРОБЛЕМ ЦИФРОВОГО МАРКЕТИНГУ
}

DOI: $10.32620 /$ cher.2021.4.16

Постановка проблеми. Ця стаття присвячена дослідженню проблем безпеки цифрового маркетингу. Блокчейн $є$ революційною технологією, яка продовжить розвиватися завдяки масовій цифровізації, що відбувається, в свою чергу, внаслідок пандемії COVID-19. Метою даного дослідження є аналіз переваг використання технології блокчейн в цифровому маркетингу. Предметом дослідження виступають гострі та актуальні проблеми цифрового маркетингу. Гіпотезою дослідження $є$ припущення, що всі блоки і коли-небудь здійснені транзакції користувачів мережі пов'язані один з одним за допомогою складних алгоритмів. Спроба змінити що-небудь в одному з блоків руйнує цілісність ланцюга і відкидається комп'ютерами інших учасників. Виклад основного матеріала. У статті охарактеризовані ключові напрямки використання технології блокчейн в цифровому маркетингу, дана характеристика нових бізнес моделей цифрових підприємств. Визначено співвідношень нових бізнесмоделей цифрової економіки. Розглянуті найбільш життєздатні блокчейн-стартапи в сфері цифрової реклами. Визначені недоліки та переваги технології блокчейн в маркетингу. Оригінальність та практичне значення дослідження. В дослідженні підкреслено, що ваємовідносини між підприємствами та споживачами переглядаються, оскільки довіра, яка зазвичай передається через посередницьке втручання, зміцнюється, а дані стають більш безпечними під контролем клієнта. Такий рівень видимості дає користувачам можливість взаємодіяти з компаніями і надавати їм доступ до їх інформації, в кінцевому підсумку змінюючи динаміку відносин з клієнтами. Висновки та перспективи подальших досліджень. Відзначимо, що вибір напрямку використання технології блокчейн дозволить підприємствам змістити значення маркетингової діяльності з просування в бік створення цифрового продукту і формування нового ланцюжка цінності для споживача.

Ключові слова:

біткоїн, цифрова економіка, інновації, бізнес моделі, блокчейн, цифровий маркетинг.

\section{BLOCKCHANE TECHNOLOGY FOR SOLVING DIGITAL MARKETING PROBLEMS}

Formulation of the problem. This article examines the security issues of digital marketing. Blockchain is a revolutionary technology that will continue to evolve due to mass digitization, which in turn is due to the COVID-19 pandemic. The purpose of this study is to analyze the benefits of using blockchain technology in digital marketing. The subject of the study are acute and topical issues of digital marketing. The hypothesis of the study is the assumption that all blocks and ever performed transactions of network users are connected to each other using complex algorithms. Attempting to change anything in one of the blocks destroys the integrity of the chain and is rejected by the computers of other participants. Presentation of the main material. The

${ }^{1}$ Дем'яненко Олена Сергї̈вна, канд. екон. наук, доцент кафедри економіки, маркетингу та міжнародних економічних відносин, Національний аерокосмічний університет ім. М. Є. Жуковського «Харківський авіаційний інститут», м. Харків, Україна.

Demyanenko Olena, Ph.D. of Economic, Associate Professor of the Economics, Marketing and International Economic Relations Department, National Aerospace University «Kharkiv Aviation Institute», Kharkiv, Ukraine.

ORCID ID: 0000-0001-5801-2643

e-mail: e.demyanenko@khai.edu

2 Дем'яненко Владислав Анатолійович, старший викладач кафедри інженерії програмного забезпечення, Національний аерокосмічний університет ім. М. Є. Жуковського «Харківський авіаційний інститут», м. Харків, Україна.

Demyanenko Vladyslav, Senior Lecturer of the Software Engineering Department, National Aerospace University «Kharkiv Aviation Institute», Kharkiv, Ukraine.

ORCID ID: 0000-0002-1078-0114

e-mail: v.demianenko@khai.edu 
article describes the key areas of use of blockchain technology in digital marketing, describes the new business models of digital enterprises. The relations of new business models of digital economy are determined. The most viable blockchain startups in the field of digital advertising are considered. The disadvantages and advantages of blockchain technology in marketing are identified. Originality and practical significance of the study. The study emphasizes that the relationship between businesses and consumers is being reviewed as trust, which is usually passed on through mediation, is strengthened and data becomes more secure under customer control. This level of visibility allows users to interact with companies and give them access to their information, ultimately changing the dynamics of customer relationships. Conclusions and prospects for further research. Note that the choice of blockchain technology will allow companies to shift the importance of marketing activities to move towards creating a digital product and forming a new value chain for the consumer.

Key words:

bitcoin, digital economy, innovation, business models, blockchain, digital marketing.

\section{ТЕХНОЛОГИЯ БЛОКЧЕЙН ДЛЯ РЕШЕНИЯ ПРОБЛЕМ ЦИФРОВОГО МАРКЕТИНГА}

Постановка проблемы. Эта статья посвящена исследованию проблем безопасности цифрового маркетинга. Блокчейн является революционной технологией, которая продолжит развиваться благодаря происходящей массовой цифровизации, в свою очередь, вследствие пандемии COVID-19. Целью данного исследования является анализ преимуществ использования технологии блокчейн в цифровом маркетинге. Предметом исследования выступают острые и актуальные проблемы цифрового маркетинга. Гипотезой исследования является предположение, что все блоки и когда-либо совершенные транзакции пользователей сети связаны друг с другом посредством сложных алгоритмов. Попытка изменить что-либо в одном из блоков разрушает цельность цепи и отвергается компьютерами других участников. Изложение основного материала. В статье охарактеризованы ключевые направления использования технологии блокчейн в цифровом маркетинге, дана характеристика новых бизнес моделей цифровых предприятий. Определены соотношения новых бизнес-моделей цифровой экономики. Рассмотрены наиболее жизнеспособные блокчейн-стартапы в области цифровой рекламы. Определены недостатки и преимущества технологии блокчейна в маркетинге. Оригинальность и практическое значение исследования. В исследовании подчеркнуто, что взаимоотношения между предприятиями и потребителями пересматриваются, поскольку доверие, которое обычно передается через посредническое вмешательство, укрепляется, а данные становятся более безопасными под контролем клиента. Такой уровень видимости позволяет пользователям взаимодействовать с компаниями и предоставлять им доступ к их информации, в конечном итоге изменяя динамику отношений с клиентами. Выводы и перспективы дальнейших исследований. Отметим, что выбор направления использования технологии блокчейн позволит предприятиям сместить значение маркетинговой деятельности по продвижению в сторону создания цифрового продукта и формированию новой цепочки ценности для потребителя.

Ключевые слова:

биткоин, цифровая экономика, инновации, бизнес модели, блокчейн, цифровой маркетинг.

Постановка проблеми. Блокчейн одна 3 найбільш трендових тем сучасності. Люди, нескінченно далекі від криптографії та ідей так званої криптоанархії, багатозначно вимовляють слово «блокчейн», часто не маючи навіть приблизного уявлення про те, що це таке.

У широкої публіки блокчейн міцно асоціюється з біткоїнами. I, хоча це два різних поняття, біткоїниїдійсно був першим «продуктом», заснованим на цій технології. Однак можливості блокчейна не обмежуються емісією криптовалют і здійсненням транзакцій, непідконтрольних третім особам. Це лише найочевидніша сфера його застосування [5, с. 381$]$.

Аналіз останніх досліджень та публікацій. Біткоїн продемонстрував життєздатність і відносну масштабованість блокчейнтехнології, а також привернув до неї увагу $з$ боку фінтеха, традиційних фінансових інститутів, органів державного регулювання і гравців найвищого рівня.

Незважаючи на фактичну складність технології, для широкого користувача цілком достатньо вникнути в загальні принципи роботи блокчейна, щоб оцінити істотні 
переваги і можливості застосування цієї технології [1, с. 28].

Метою статті $\epsilon$ аналіз переваг використання технології блокчейн в цифровому маркетингу.

Виклад основного матеріалу дос-лідження. 1. Децентралізація

Блокчейн - це розподілена база даних. Не існує єдиного дата-центру -інформація зберігається на комп'ютерах кожного з учасників мережі. Причому зберігається цілком: весь блокчейн на кожному з пристроїв.

Таким чином, можна вивести з ладу 99\% апаратів (що практично неможливо, якщо мова йде про мільйони копій блокчейна по всьому світу), але 1\% 3 них збереже всю базу даних в цілості й схоронності. I неодмінно передасть її всім новим пристроям, що підключилися до мережі.

2. Неможливість внесення недостовірних даних або зміни вже зроблених записів.

На відміну від інших баз даних, вся інформація, що записується в блокчейн, взаємопов'язана. Блокчейн складається з ланцюжка блоків, вибудуваного в хронологічному порядку. До першого блоку (так званого genesis block) прикріплюється другий, до другого - третій і так далі. При цьому кожен новий блок, що додається в ланцюжок, містить інформацію про попередній.

Таким чином, всі блоки і коли-небудь здійснені транзакції користувачів мережі пов'язані один з одним за допомогою складних алгоритмів. Спроба змінити що-небудь в одному з блоків руйнує цілісність ланцюга і відкидається комп'ютерами інших учасників. Справжність кожного нового блоку також перевіряється учасниками, і при досягненні загального консенсусу він додається в ланцюжок.

У кожному блоці зберігається інформація про дії користувачів. Якщо мова йде про блокчейн біткоїни, то в блок записуються дані про останні транзакції, проведених користувачами. Однак теоретично в блокчейн можна записувати будь-яку інформацію, яку необхідно зробити одночасно загальнодоступною і захищеною від будьякого редагування або видалення.

3. Унікальність і в той же час анонімність учасників
Всі користувачі мережі, на основі блокчейну, мають унікальний ідентифікатор і цифровий підпис. При цьому реальні особисті дані людини можуть залишатися або конфіденційними, або загальнодоступними - в залежності від бажання користувача або вимог, закладених в алгоритмі конкретного блокчейну.

Перший серйозний інтерес до блокчейну проявив Фінтех. По-перше, блокчейн був вже добре «обкатаною» технологією платіжна мережа Bitcoin, незважаючи на деякі спірні моменти, пов'язані з тіньовою економікою і спекуляцією, продемонструвала виняткову функціональну стабільність. Досі не було зареєстровано жодного випадку успішного злому мережі.

По-друге, використання блокчейну у фінансових операціях дозволяє:

усунути посередників і перевіряючих третіх осіб від будь-яких угод;

забезпечити повну публічність і прозорість всіх дій;

вирішити питання довіри, автоматизуючи угоди. Блокчейн Ethereum дозволяє створювати так звані смарт-контракти, які виконуються автоматично в міру виконання сторонами своїх зобов'язань;

вирішення проблем довіри і контролю в digital-маркетингу.

Саме смарт-контракти і багатофункціональний блокчейн на зразок Ethereum дозволяють вийти за рамки фінтеха і зробити взаємини зацікавлених сторін абсолютно прозорими - в будь-яких сферах людської діяльності, де мають місце будь-які домовленості і зобов'язання.

Щоб зрозуміти, чим саме блокчейн може бути корисний для ринку digital-реклами, необхідно позначити найбільш гострі та актуальні проблеми цифрового маркетингу.

Фрод. Справжній бич цифрової реклами. Закуповуючи покази на будь-яких майданчиках, ви можете витратити даремно більше 50\% рекламного бюджету, так як разом $з$ реальними користувачами ваші оголошення будуть переглядати боти.

Розкриття ботнету Methbot наприкінці 2016 року продемонструвало жахливі масштаби клік-фроду. У сукупності індустрія цифрової реклами втрачає близько $\$ 7$ млрд 
щорічно через фейкові перегляди оголошень. I поки підхід до розміщення реклами в цифровому середовищі не зміниться, цей показник буде тільки зростати.

Примітно, що зараз захисту від ботів, які автоматично переглядають оголошення, практично не існує. Якою б системою аналітики ви не користувалися, немає ніяких гарантій, що перегляди, які відображаються, були здійснені реальними людьми.

Посередник. В умовах, коли не можна довіряти майданчику безпосередньо, рекламодавці змушені працювати 3 посередниками, які грають роль арбітрів. Проблема в тому, що арбітри не завжди добре справляються зі своїми завданнями - величезна кількість фроду - тому підтвердження.

Крім того, посередники між рекламодавцем і майданчиком беруть за свої послуги істотну комісію. Якщо ми розглянемо найбільших посередників - таких як Google або Facebook, - то виявимо, що на їх частку припадає значна частина всіх маркетингових витрат. Величезна влада над ринком цифрової реклами і неоднозначна ефективність - те, що відрізняє цих гравців.

Facebook, наприклад, налічує близько 2 мільярдів користувачів по всьому світу. Такий масштаб аудиторії в поєднанні з big data забезпечує соцмережі значний вплив на цифровий маркетинг в цілому. На думку багатьох маркетологів - навіть занадто значний.

Компанії, подібні Facebook, стали являти собою «цифрові сади даних, оточені стіною» (walled gardens of data). Маркетологи вважають, що вони мають право претендувати на частину цих даних. Тим часом використання блокчейну в digital-маркетингу може закрити питання фроду і посередників назавжди. І ось чому.

Блокчейн здатний забезпечити унікальність, «реальність» учасника мережі і його анонімність в один і той же час. Ми можемо розглядати показ оголошення як угоду між рекламодавцем, власником сайту і користувачем, при цьому гарантом виконання зобов'язань служить не третя сторона (як Google, Facebook або «Яндекс»), а блокчейн.

Цифрова ідентифікація без передачі персональної інформації дозволить запобі- гти фроду будь-якого типу, захистивши користувача від недобросовісного використання його особистих даних.

Блокчейн також здатний (в перспективі) завдати серйозного удару по посередникам, надавши можливість прямого контролю над розміщенням оголошень і витратами рекламних бюджетів. Поки даними статистики по рекламних кампаніях можна відносно легко маніпулювати, з перекладом же угод на блокчейн-основу, підробка статистики стане неможливою.

Продукти, що дозволяють використовувати блокчейн в digital-маркетингу, активно розвиваються. Ми знаходимося на самому початку шляху перекладу цифрової реклами на блокчейн-основу, i різні стартапи пропонують свої способи застосування технології.

MetaX - adChain - набір відкритих протоколів на основі блокчейну Ethereum. На поточному етапі реалізований протокол, що дозволяє учасникам мережі голосувати за включення того чи іншого сайту в «білий» список майданчиків (сайтів, які не користуються накрутками і вільні від фроду). При досягненні консенсусу всіма учасниками мережі, сайт додається в список. Користувачі Мережі adChain виступають власниками токенів adToken - ADT - криптовалюти, прив'язаної до Ethereum. Власник сайту, який подав заявку на включення свого домену в «білий» список, вносить заставу у вигляді токенів, після чого протягом деякого часу користувачі Мережі можуть оскаржити заявку, також розмістивши для цього заставу в токенах.

У підсумку, якщо більшість користувачів не поставило під сумнів легітимність майданчика, він вноситься в «білий» список.

Маркетологи, як і самі засновники adChain, не вважають схему ідеальною. Зрештою, саме люди створюють реєстр «білих» сайтів. Крім того, для користувачів системи поки немає істотних стимулів для схвалення або оскарження доданих доменів.

Втім, це лише перший протокол, представлений стартапом. Розробники анонсують нові механізми для підвищення контролю над рекламними кампаніями.

New York Interactive Advertising Exchange (NYMEX) 
NASDAQ, найбільша американська біржа, що торгує акціями високотехнологічних компаній, анонсувала NYIAX - першу біржу для торгівлі рекламним інвентарем преміум-рівня. Майданчик розпочав роботу наприкінці 2017 року.

Виконання контрактів, що укладаються гравцями NYIAX, автоматизовано за допомогою блокчейна. При виконанні взятих зобов'язань обома сторонами угода вважається укладеною. Перший час на біржі торгували цифровим рекламним інвентарем, потім розміщували і більш традиційну ТВрекламу.

Проект Basic Attention Token також заснований на блокчейні Ethereum, однак, замість простого голосування і білих списків, стартап претендує на створення цілої рекламної екосистеми, в рамках якої рекламодавці, майданчики і користувачі обмінюються токенами BAT (знову ж пов'язаними з криптовалютою Ethereum).

Користувачі, які бажають стати учасниками проекту, повинні встановити браузеp Brave. Його особливість полягає в забезпеченні високого ступеня анонімності користувача: будь-які спроби таємного збору даних $з$ боку сайтів, які відвідує користувач, блокуються. Також браузер володіє вбудованим adblock-механізмом - будь-яка стороння реклама в ньому за замовчуванням блокується.

При цьому Brave відстежує активність користувачів і пропонує їм перегляд релевантної, перевіреної і безпечної реклами за винагороду, що нараховується в токенах ВАT. У свою чергу майданчики, що розміщують рекламу, отримують токени за кожен перегляд оголошення.

Всі користувачі мережі зберігають повну анонімність. Таким чином досягається ідеальний баланс між конфіденційністю для користувача i точним таргетингом для рекламодавця, який оплачує тільки кліки реальних цільових користувачів. У майбутньому проект анонсує можливість для користувачів повністю відключати рекламу. Ця опція також буде оплачуватися токенами ВАТ.

BAT (Basic Attention Token).- поки найбільш ефективний спосіб боротьби 3 фродом і посередниками в digital-маркети- нгу, заснований на блокчейні. Єдине серйозне обмеження, яке може перешкодити розвитку проекту, - його прив'язка до окремого браузеру. Ймовірно, якщо розробники зможуть перенести функції Brave в Firefox або Chrome за допомогою розширень, проект чекає велике майбутнє [4, с.54].

$\mathrm{AdEx}$ - децентралізована рекламна біржа

За принципом роботи AdEx схожий 3 проектом ВАТ. Він також був заснований на блокчейні Ethereum (згодом розробники перейшли на приватний Китайський блокчейн NEO) і має власні токени ADX.

$\mathrm{AdEx}$ являє собою рекламну біржу, угоди всередині якої здійснюються за допомогою смарт-контрактів, що забезпечують захист рекламодавців, видавців і користувачів від шахрайства, неприйнятної реклами і використання конфіденційних даних.

Завдяки блокчейну, рекламодавець зможе отримувати достовірну, підтверджену статистику про покази реклами. Точний таргетинг і релевантність самих оголошень забезпечують користувачі: на особистій сторінці профілю AdEx вони керують рекламою і бачать тільки той контент, який відповідає їх інтересам [3].

Проект передбачає забезпечити максимально тонке налаштування таргетингу - аж до, припустимо, максимальної суми, яку конкретний користувач готовий витратити на подорож в певне місце (якщо мова йде про любителів подорожей і відповідної реклами).

Що стосується рекламних майданчиків, то вони отримують всю повноту влади над тим контентом, який з'являється на їхніх сторінках. У тому числі вони будуть мати можливість прийняти або відхилити ставку рекламодавця. Це особливо важливо, коли майданчик приділяє велику увагу своїй репутації і точному відстеженню тієї реклами, яка показується користувачам.

На жаль, сучасні рекламні мережі не завжди показують ту рекламу, яка прийнятна для майданчика, так як робота їх алгоритмів часто не дуже передбачувана.

Блокчейн може істотно вплинути на якість обслуговування клієнтів, але успішне впровадження буде багато в чому залежати 
від того, як компанії використовують технологію, щоб переосмислити точки дотику на шляху користувача. У маркетологів $\epsilon$ можливість використовувати блокчейн для управління безпечною мережею програм лояльності, призначених для залучення нових клієнтів.

Пов'язуючи контент з віртуальним токеном, що зараховується на рахунок клієнта, компанії можуть використовувати блокчейн, щоб спонукати користувачів обмінювати бали лояльності в режимі реального часу.

Зробивши ще один крок вперед, можна використовувати цифрові гаманці, щоб користувачі могли погашати свої кредити в зручний для них час. У свою чергу, маркетологи можуть використовувати ці дані, щоб отримати чітке уявлення про свою клієнтську базу, щоб підвищити обізнаність про новий продукт i підвищити коефіцієнт конверсії.

Після продажне обслуговування є важливим фактором, що визначає відтік клієнтів, оскільки споживачі прагнуть повноцінного безперервного обслуговування. Самообслуговування швидко стало популярним серед клієнтів, які віддають перевагу онлайн-допомозі замість звернення до агентів підтримки. Блокчейн, якщо він правильно розроблений і налаштований, здатний автоматизувати ці допоміжні транзакції і зберігати ці цінні дані в блоках, до яких клієнти можуть отримати доступ.

Те, що відрізняє цю платформу від традиційних платформ самообслуговування, полягає в тому, що клієнти контролюють свої дані і можуть вибрати миттєву платну підтримку, збільшуючи доходи і скорочуючи час обробки.

Більш широкий доступ до зручної інформації про клієнтів також дозволяє маркетологам проводити кампанії з урахуванням потреб користувачів 3 розширеною персоналізацією. Це може допомогти протидіяти негативному відношенню до взаємодії, в якому відсутня персоналізація.

Хоча маркетологи платять за збір даних про стимули, маркетинг за допомогою блокчейн допомагає надавати персоналізовані ціни і залучати більше потенційних клієнтів. Цей розумний підхід вирішує загальну проблему обтяження неповною інформацією про клієнтів, яка зазвичай може перешкоджати успіху маркетингових кампаній.

Оскільки блокчейн продовжує набирати обертів в маркетинговому просторі, технологія виявиться керованою і масштабованою областю інвестицій для брендів у всіх галузях.
Ця технологія підриває традиційні моделі цифрового маркетингу, здатні підвищити прозорість і спростити роботу.

Взаємовідносини між підприємствами та споживачами переглядаються, оскільки довіра, яка зазвичай передається через посередницьке втручання, зміцнюється, а дані стають більш безпечними під контролем клієнта. Такий рівень видимості дає користувачам можливість взаємодіяти 3 компаніями і надавати їм доступ до їх інформації, в кінцевому підсумку змінюючи динаміку відносин з клієнтами.

Висновки та перспективи подальших досліджень. Підводячи підсумок, в 2022 році від блокчейн-технологій можна очікувати тільки позитивних змін.

Блокчейн-рішення допоможуть викорінити рекламне шахрайство, яке зазвичай вражає сектор, доводячи свою цінність в подоланні проблем неефективності даних

Блокчейн може істотно вплинути на якість обслуговування клієнтів, але успішне впровадження буде багато в чому залежати від того, як компанії використовують цю технологію, щоб переосмислити точки дотику на шляху користувача.

У маркетологів є можливість використовувати блокчейн для управління безпечною мережею програм лояльності, призначених для залучення нових клієнтів. Якщо блокчейн правильно розроблений і налаштований, він здатний автоматизувати ці допоміжні транзакції і зберігати цінні дані в блоках, до яких клієнти можуть отримати доступ.

Але не потрібно забувати і про недоліки цієї технології. Багато хто сприймає технологію блокчейн як панацею від цифрового шахрайства і неефективних посередників. Більшою мірою ентузіазм поділяють представники фінтеху, в меншій - digital-маркетологи $[6$, c. 75$]$.

Основна причина банальна - поки маркетологи в масі своїй все ще погано розуміють принципи роботи блокчейну і не цілком усвідомлюють ті практичні можливості, які він дає. Але є також і технічні обмеження, що перешкоджають негайному і тотальному впровадженню блокчейну в сферу цифрової реклами.

По-перше, блокчейн досі не прийнятий індустрією в якості стандарту. Робота технології залежить від численних вузлів, функціонування яких забезпечують учасники мережі або ентузіасти, або зацікавлені сторони. Якщо 
в мережі мало учасників, вона не буде ефективною і працездатною.

По-друге, блокчейн - багато в чому теоретична розробка, практичне використання якої залишається поки досить нішевим явищем. Повноцінна реалізація ідей, декларованих в останній рік численними блокчейн-стартапами, може зайняти роки.

По-трете, серйозне технічне обмеження - це масштабованість блокчейн-транзакцій. Наприклад, блокчейн Ethereum, найбільш популярний і функціональний сьогодні, дозволяє здійснювати 20 транзакцій в секунду. Така швидкість не йде ні в яке порівняння 3 тим, як швидко працюють RTB-Аукціони.

Узагальнюючи матеріал, відзначимо, що вибір напрямку використання технології блокчейн дозволить підприємствам змістити значення маркетингової діяльності з просування в бік створення цифрового продукту і формування нового ланцюжка цінності для споживача.

\section{Література}

1. Блокчейн-револючія. Як технологія, щзо лежить в основі біткойна та інших криптовалют змінює світ / Дон Тапскотт, Алекс Тапскотт; [пер. 3 англ. Г. Лелів, Ю. Григоренко]. Львів : Літопис, 2019. 488 с.

2. Вінья П., Кейсі М. Епоха криптовалют. Як біткони і блокчейн змінюють світовий економічний порядок. НьюЙорк: Раn Books Limited, 2017. 432 c.

3. Офіційний портал блокчейн-коропрації IBM. Проєкт IBM MAERSK [Електронний pecypc]. URL: https://www.ibm.com/ search?lang=en\&cc=us\&q=Maersk (дата звернення: 24.09.2020)

4. Harris T. Bitcoin: Mastering Bitcoin \& Cyptocurrency for Beginners. Нью-Йорк:

Стаття надійшла

до редакції : 10.09.2021 p.
CreateSpace Independent Publishing Platform, 2016. $86 \mathrm{c}$.

5. Яцків Н. Г. Перспективи використання технології блокчейн у мережі інтернет речей. Науковий вісник НЛТУ Украӥни. 2016. № 26. С. 381-387.

6. Власов А. І., Карпунін А. А., Новіков I. Р. Системний аналіз технології обміну та зберігання даних блокчейн. Сучасні технологіï. Системний аналіз. Моделювання. 2017. № 3 (55). С. 75-83.

\section{References}

1. Tapscott, D., Tapscott, A. (2019). Blockchain revolution. How the technology underlying bitcoin and other cryptocurrencies is changing the world. Ttrans. from English G. Leliv, Y. Grigorenko. Lviv: Litopys, 488.

2. Vinya, P., Casey, M. (2017). The era of cryptocurrencies. How bitcoins and blockchain are changing the world economic order. New York: Pan Books Limited, 432.

3. Official IBM blockchain corporation portal. IBM MAERSK project. Retrieved from: https://www.ibm.com/ search? Lang = en \& cc = us $\& \mathrm{q}=$ Maersk (access date: 24.09.2020)

4. Harris, T. (2016). Bitcoin: Mastering Bitcoin \& Cyptocurrency for Beginners. New York: CreateSpace Independent Publishing Platform, 86.

5. Yatskiv, N. G. (2016). Prospects for the use of blockchain technology in the Internet of Things. Scientific Bulletin of NLTU of Ukraine, 26, 381-387.

6. Vlasov, A. I., Karpunin, A. A. and Novikov, I. P. (2017). System analysis of blockchain data exchange technology and storage. Modern technology. System analysis. Modeling, 3 (55), 75-83.

Стаття прийнята
до друку: $30.12 .2021 \mathrm{p}$.

\section{Бібліографічний опис для цитування :}

Дем'яненко О. С. Технологія блокчейн для рішення проблем цифрового маркетингу / О. С. Дем’яненко, В. А. Дем'яненко // Часопис економічних реформ. - 2021. - № 4 (44). C. $117-123$. 